\title{
The Concept of Ideology in Marxist Literary Criticism
}

\author{
Lutfi Hamadi, (PhD) \\ Lebanese University, Lebanon
}

doi: 10.19044/esj.2017.v13n20p154 URL:http://dx.doi.org/10.19044/esj.2017.v13n20p154

\begin{abstract}
This paper attempts an exploration of the development of the Marxist literary theory in general and the concept of ideology in particular. Showing the significant role this theory plays in the field of literary criticism, the paper focuses on remarkable Marxist figures, explores their most notable works, and sheds light on their contributions to the theory and the field of literary criticism. For this purpose, the paper starts with basic Marxist principles of reading literature set by Marx and Engels and examines the changes that occurred with other critics, mainly Althusser, Jameson, and Eagleton in their attempts to show the importance of ideology in explaining literature and understanding its backgrounds, goals, and methods. Thus, the methodology will include an historical overview, shedding light on early Marxist perspectives, comparing and contrasting the contributions and adjustments added by remarkable Marxist thinkers, and illustrating by examples of literary texts and how they are seen and analyzed by these Marxist scholars.
\end{abstract}

Keywords: Ideology, Marxism, Literary Criticism

\section{Introduction}

Literary criticism in Western universities has been profoundly altered in the last few decades to the extent that it seems it has almost become impossible to restrict criticism to pointing out the beauties in poems, novels, plays, or even in paintings and architecture. An academic critic nowadays has to make it clear whether his point of view is structuralist, semiotic, deconstructionist, psychoanalytical, feminist, or Marxist. According to Raman Selden in Theory of Criticism (1988), 'The Moderns appear to regard traditional critics (even new critics) as prehistoric moles working in the dark before the dawn of" (1) these new theories. Because of the increasingly significant role Marxism has been playing in literary criticism, this paper is an attempt to throw light on Marxist literary criticism in general and on the 
development of the concept of ideology in the works of Marx, Althusser, Jameson, and Eagleton in particular.

Concerning methodology, several methods will be consistently employed in this study, mainly the comparative method, which will be extensively used to show the similarities and differences in the Marxist thinkers' points of view while tracing the development that Marxist literary theory has undergone. Consequently, this method is necessary to compare and contrast such views in order to examine, interpret, and conclude. Historical materials and allusions will be employed in order to shed light on the influence of the dominating ideology during a certain period on the literary works of this or that period. Besides, this study will be supported by a number of examples of such works, showing how they were interpreted by Marxist thinkers or other critics, a fact that necessitates the use of books and articles written by major theorists and scholars.

\section{I.}

Marxism views works of literature or art as the products of historical forces that can be studied by looking at the material conditions in which they are produced. This theory generally focuses on the conflict between the dominant and repressed classes in any given age. In other words, Marxist literary theory starts from the assumption that literature must be understood in relation to historical and social reality of a certain society.

As a matter of fact, Marxist literary theory has passed through a variety of changes and developed by a notable group of critics since Marx and Engels wrote the Communist Manifesto in 1848. In his Twentieth Century Literary Theory: A Reader (1997), K. M. Newton distinguishes between Marxist and Neo-Marxist criticism, saying that the most direct form of Marxist criticism, or the so-called 'vulgar' criticism, takes the view that 'there is a straightforward deterministic relation between base and superstructure” (158). The base, to Marxists, is the economic system on which the superstructure rests, while cultural activities, including philosophy and literature, belong in the superstructure. Marx believes that because the superstructure is determined by the base, it inevitably supports the ideologies of the base. Ideologies are the changing ideas, values, and feelings through which individuals experience their societies. They present the dominant ideas and values as the beliefs of society as a whole, thus preventing individuals from seeing how society actually functions. Literature, according to Marxists, is a form of ideology, one that legitimizes the power of the ruling class. In A Critique of The German Ideology (1846), Marx emphasize that Marxist critics have to tackle literature, literary education, criticism, and theory as integral parts of economic, political, and social life, not produced 
by totally independent writers. "The production of ideas, of conceptions, of consciousness, is at first directly interwoven with the material activity and the material intercourse of men, the language of real life" (9). To Marx, 'ideology critique' is the exposure of how class interests really operate through cultural forms, whether political, legal, religious, philosophical, educational, or literary. According to Leitch in The Norton Anthology of Theory and criticism (2001), Marx believes that ideology tries to hide "the reality of class struggle from our perception and consciousness; and insofar as working-class people unconsciously absorb bourgeois values, they are unwitting carriers of 'false consciousness"' (762). Because such ideologies do not usually show themselves clearly and directly in literary works, a critic should less analyze what a text says than what it does not say. Marx believed that all mental systems, or ideologies, were the products of social and economic realities. Thus, to Marxism, analysis and understanding of a literary work has to refer to the modes of production in a certain society during a certain historical period. In Economic Manuscripts (1863), Marx argues that "A writer is a productive labourer not in so far as he produces ideas, but in so far as he enriches the publisher who publishes his works, or if he is a wage-labourer for a capitalist" (304). Relating literature to the prevailing social and economic conditions in his Introduction to the Critique of Political Economy (1859), Marx compares Greek art to that of the present time showing that the importance of mythology (not the Egyptian, for example), and nature in the Greek culture made it possible for them to produce certain forms of art. Then Marx asks, "Is the conception of nature and of social relations which underlies Greek imagination and therefore Greek (art) possible when there are self-acting mules, railways, locomotives and electric telegraphs" (128)?

Therefore, according to Marx, the history of humankind is that of struggle between social classes, where what is considered the culture, or the superstructure of a certain society is actually the articulations of the dominant class. In the Communist Manifesto (1848), as S. S. Sprawer writes in Karl Marx and World Literature (1978), the term literature refers to "the body of technical books, pamphlets, etc., that treat a given subject, and the writers who produce it” (140). According to the Manifesto, with the emergence of the bourgeois and their arrival to power, the aristocracies found a serious political struggle out of the question, so "a literary battle alone remained possible" (141), thus starting to write pamphlets against modern bourgeois society. The Manifesto asserts that literature is turned to serve the ideology of the dominant class - the bourgeoisie in this case - that "has converted the physician, the lawyer, the priest, the poet, the man of science, into its paid wage labourers" (142). So, for Marx, literature is not a separate, self-enclosed region, and literary works are not isolated from social 
and political conditions. The Manifesto goes further to show how the bourgeoisie has changed modes of production surpassing national boundaries to every quarter of the globe, turning literature in the process to a world literature. Leitch sees that ideology, according to Marxism, "consists of the ideas, beliefs, forms, and values of the ruling class that circulate through all the cultural spheres" (14). He adds that culture and arts in the Marxist view can never be innocent entertainment, nor can they be independent of social forces, as they play a significant role in relaying ideology.

Benefiting from the advances in various sciences, a succeeding generation of Marxist thinkers and critics pursued the effort to extend and systematize the theoretical work of Marx and Engels. Among these remarkable names are Antonio Gramsci, Walter Benjamin. Georg Lukacs, Theodore Adorno, Raymond Williams, Louis Althusser, Fredric Jameson and Terry Eagleton. These and other Marxist thinkers have developed both the positive and negative senses of ideology. Gramsci, for example, describes ideology in his Prison Notebooks as "the terrain on which men move, acquire consciousness of their position, struggle, etc." (qtd in Leitch 762). Nevertheless, he also contends that by using ideology, those in power can attain cultural hegemony and their thoughts and values prevail.

The concept of ideology has been a central idea in the works of several Marxist critics, mainly Althusser, Jameson, and Eagleton for its influential role in literary criticism. These critics, however, haven't restricted their ideas to the basic cultural constructions of Marxist thought, as they have also contributed to the diversity of Marxist intellectual life, enriching and developing its inherited canon. According to Mulhern, "'contemporary Marxist literary criticism' is not a stable entity, or even a phase in the history of a settled lineage" (2).

The French theorist Louis Althusser (1918-1990) was well-known for his anti-humanist Marxism, where his essay "Marxism and Humanism" (1964) condemns ideas like "human potential" and "species-being," which are often put forth by Marxists, considering them as an outcome of a bourgeois ideology of "humanity." In this respect, Vincent Leitch believes that "Althusser's interventions changed the face of Western Marxist theory, shattering the pieties of Stalinist dogmatism and the newer Marxist humanism." (1476). Instead of humanism which stresses human freedom and self-determination, Althusser emphasizes the scientific aspects of Marxism, "in particular its investigation of how societal structures determine lived experience" (1476). In For Marx (1965), Althusser sees that art is something between science and ideology, the latter being a representation of the imaginary relationship of individuals to the real conditions of their existence. Art, for him, is therefore not entirely a fiction, nor of course the view of its 
author. In his most influential essay "Ideology and Ideological State Apparatuses" (1970), Althusser analyzes how controlling social systems shape human subjects through ideology, believing that both the base and superstructure are intertwined. He asserts that our desires, choices, intentions, preferences, judgments and so forth are the consequences of social practices, so it is necessary to realize how society makes the individual in its own image. Like Marx, he thinks that our values are inculcated in us by ideological practice, thus constituting individuals as subjects. So, to him, the human individual in capitalist societies is regarded as being able to see himself as a conscious responsible agent. Yet, as a matter of fact, this is, definitely, not an innate property, but is rather acquired or even imposed on him within the structure of established social practices. To shed more light on this perspective, Althusser explains how capitalism reproduces the labor power it needs through not only wages but also outside production by the capitalist education system, and by other instances and institutions.

To Althusser, what children learn at school is a number of techniques "of 'scientific' or 'literary culture', which are directly useful in the different jobs in production" (Leitch 1485). In other words, the education system, as well as other ideological 'apparatuses' such as the church and the army, devised by the ruling class, teaches subjects how to be morally and professionally useful to this system through "rules of respect for sociotechnical division of labour and ultimately the rules of the order established by class domination" (1485). This simply means subjugation to the rules of the established order and sincere performance of their duty towards the system. All these institutions generate ideologies, which we as individuals then internalize and act in accordance with, having the illusion that we are in control, and that we are free to believe the things we believe. But the truth, according to Althusser, is that the material alienation of real conditions drives people to form representations, to make up stories, and invent illusions that distance them from these real conditions.

An essential aspect of Althusser's perspectives is the relationship of his theory of ideology to literature. A literary work, as production of ideology, also constitutes us as subjects and speaks to us directly, exactly as a commercial does and makes us feel that it is addressing us personally. So, dominant ideology works through the messages of the mass media, which means that ideologies exist in the very 'apparatuses' and practices of the cultural institutions of the dominant forces - the state. Through such media, individuals believe they are willingly and freely participating in certain practices such as voting, not realizing they are subjected by ideology. Althusser calls this 'interpellation', as ideology interpellates individuals as subjects through, say, a literary work, which addresses them directly or indirectly by some mechanism or another. 
Perhaps the best work in which Althusser's explains the relationship between literature and ideology is "A Letter on Art in Reply to Andre' Daspre" (1966). Admitting that this is a very complicated and difficult relationship, he sees that this necessitates an understanding of hegemony. Suggesting that ideology and hegemony, like literature, reconstruct reality without necessarily reflecting the actual conditions of life, he believes that literature may be located within ideology, but it can also be kept at bay from it, allowing the reader to gain an awareness of the ideology on which it is based. So a novel may present the world in a way that seems to support dominant ideologies, but, as a work of fiction, it may also reveal those ideologies. Thus, literature neither merely reflects ideology, nor can it be reduced to it. In other words, Althusser rejects the notion that art works are wholly determined by socio-economic forces, arguing that they have a relative autonomy determined by a complex set of factors. Advising the reader to read carefully Pierre Macherey's article, "Linen as a Critic of Tolstoy", Althusser reasons that authentic art makes us feel, see, or perceive something that alludes to reality, but it doesn't make us know reality. Unlike science, according to Althusser, what art "gives to us in the form of 'seeing', 'perceiving' and 'feeling' (which is not the form of knowing), is the ideology from which it is born, and to which it alludes" (Leitch, 1480). He asserts that ideology slides into human activity, and that it is identical with the lived experience of human existence itself. He contradicts the saying that Balzac, for example, was forced by the logic of his art to abandon certain of his political conceptions in his work as a novelist, asserting that Balzac's peculiar "reactionary political positions played a decisive part in the production of the content of his work.... Only because he retained them could he produce his work, only because he stuck to his political ideology could he produce in it this internal 'distance' which gives us a critical 'view' of it" (1482). Althusser concludes that while reading a work of art, and in order to know the mechanisms which produce the aesthetic effect, we should spend a long time and pay the greatest attention to the basic principles of Marxism; otherwise, what we will get to is not knowledge, but "ideology of art" (1483).

In short, before Althusser, Marxist criticism was mainly of interest to those committed to Marxism as a system, but with him, Marxist criticism has had a much wider influence, having in mind that Marxist thinking has reached productive interaction with other sets of ideas. Newton assures that "Althusser's work created mental space for critics who were sympathetic to the political aims of Marxism but unhappy at the restrictive nature of most earlier Marxist criticism" (159). 
Among the notable critical figures influenced by Althusser is the American literary critic and Marxist political theorist Fredric Jameson (1934). According to Newton, Jameson has been much influenced by Althusserian concepts, and he supports using Marxism together with contemporary theories such as post-structuralism and psychoanalysis, but he differs from Althusser by believing in the Hegelian totalizing type since, for him, "Marxism can subsume and incorporate within itself all other forms of thought" (159).

Influenced by several other Marxist thinkers, Jameson is best known for the analysis of contemporary cultural trends, viewing cultural criticism as an integral feature of Marxist theory. He has been concerned to show Marxism's relevance to current philosophical and literary trends, thus his involvement in Western Marxism, which, unlike the vulgar Marxist view of ideology, sees that the culture "superstructure" is not totally determined by the economic base. Using the Hegelian concept of immanent critique, new Western Marxists believe that the best way to analyze and criticize a philosophical or cultural text is to employ the same terms used by the text itself. Jameson believes that cultural objects must be understood according to cultural rules, arguing that careful and detailed analysis of cultural practices would reveal the interrelation between culture and economic realities. Believing that mainstream in literary and academic life is tending toward detachment from reality, he agrees on neither studying the work of art separated from the context of its production, nor restrictively using the structuralist method and the anti-historical formalism. So he insists that the work of art should be seen in terms of historical literary practices and norms, not merely in purely aesthetic terms. In this respect, he criticizes, but does not reject, postmodernism on the basis that it suffers from a crisis in historicity while trying to show that what is done in the lived experience has nothing to do with history. In interviews with Jameson, excerpts from which are published on the Stanford Presidential Lectures Website, he criticizes the approach of teaching literature to undergraduates, believing that students never really confront the text in all its material freshness. On the contrary, they analyze it depending on a whole set of previously acquired and culturally sanctioned interpretive methods, or ideologies, which are proposed to them. He suggests using what he calls "the fruitful Althusserian concept" and "make those interpretations visible, as an object, as an obstacle rather than a transparency, and thereby encouraging the student's selfconsciousness as to the operative power of such unwitting schemes, which our tradition calls ideologies" (1). Consequently, Jameson affirms, the student's first confrontation with a classic by Conrad, for example, doesn't at all involve an unmediated contact with the object itself, "but only an illusion of contact, whose terminus turns out to be a whole range of interpretive 
options, from the existential one ... all the way to ethics" (1). Jameson concludes that using these various liberal ideologies contribute to the repression of the social and the historical, and "in the perpetuation of some timeless and a historical view of human life and social relations" (1). What he calls for is a critical struggle which is more moralistic, and which takes a more combative position in order to "restore a presence of social struggle to texts, some of which may be exceedingly rarefied" (2).

In his article "Fredric Jameson", Douglas Kellner analyzes Jameson's first published book, Sartre: The Origins of a Style (1961), seeing that Jameson attempts to enforce himself as a critical intellectual against the conformist currents of the epoch. Kellner believes that Jameson turns against the literary establishment, and that all Jameson's works "constitute critical interventions against the hegemonic forms of literary criticism and modes of thought regnant in the Anglo-American world" (1). Not unlike Althusser, Jameson has shifted his focus from a vertical emphasis on the many dimensions of a text, "its ideological, psychoanalytic, formal, mythicsymbolic levels ... to a horizontal emphasis on the ways texts are inserted into historical sequences and on how history enters and helps constitute texts" (2). Although Jameson has used a wide range of theories in his literary studies such as Structuralism, poststructuralism, psychoanalysis, and postmodernism, Marxism remains the master narrative of Jameson's corpus, in which he criticizes "the ideological components of cultural texts, while setting forth their utopian dimension" in an attempt to "produce criticism of existing society and visions of a better world" (2).

In the introduction to his remarkable book Theory and the Novel (1998), Jeffrey J. Williams explores how different critical theories, including Marxism, feminism, deconstruction, and postmodernism, analyze classic novels according to specific limited methods, emphasizing the role of ideology in such texts and critics' attempts to deconstruct and analyze this role for a more comprehensive understanding of these texts. Very similar to Althusser, Jameson, according to Williams, believes that such works of literature advertise not only how people should behave, how love and marriage and other social relations should properly proceed, but also how necessary and desirable the narrative itself has become. Referring to what Williams calls "a magisterial synthesis of the formal and historical strands of reading Lord Jim (1900), Fredric Jameson construes [the novel] along the axes of a set of structural oppositions ... that reveal what he calls ideology of the form" (174). Williams goes on to consider that Jameson's both poststructural and historical reading leads to perspectives which symbolically enact "the ideological cohesion of the community of imperial managers, joined by their narrative investment," where Lord Jim "foregrounds the 
continual confirmation of their ideological bond, spurred by and dispelling the negative ideological example of Jim" (175). Needless to say, such analysis of Conrad's novel clearly reminds of Edward Said's Orientalism (1978), in which he shows the effect of imperial ideology which stereotypes the Orient and Orientals, so "standardization and cultural stereotyping have intensified the hold of the nineteenth-century academic and imaginative demonology of the 'mysterious orient'” (26). Similarly, Elleke Boehmer in Colonial and Postcolonial Literature (1995) analyzes Conrad's Lord Jim arguing that although Jim was a flawed protagonist, he was given another chance to prove his manhood and heroism on a lesser type of human beings, the natives in the Malayan archipelago. According to Boehmer, "Despite his failings, Marlow sees Lord Jim as possessing an internal nobility and quality of leadership that distinguishes him from the people of Patusan" (86). If this proves something, it does illustrate the inescapable influence of ideology on literature and even on great literary figures like Conrad. Williams concludes that those with whom Marlow identifies are those of professional positions, the ones who manage the imperial mission, rather than the ruling class.

In his landmark The Political Unconscious: Narrative as a Socially Symbolic Act, Jameson focuses not on the literary text itself, but rather on the interpretive frameworks by which it is now constructed. So, instead of viewing the work of art in purely aesthetic terms, it is seen in terms of historical literary practices and norms. This book argues that political and economic history forms the subtexts and allegorical meanings of literary works. Leitch sees this book as an "ambitious synthesis of contemporary structuralist theory and Marxism" (1933). Like Althusser and other Marxists, Jameson argues that to decipher the meaning of a text, the critic should examine in turn the political history to which a text refers, social history, and the history of modes of production. Following this procedure, one can read Shakespeare's Macbeth as a presentation of the agitating political condition of its historical moment, short after James VI of Scotland had assumed the English throne. At another level of interpretation, the object of investigation, Leitch contends, is "the ideologeme, that is, the smallest intelligible unit of the essentially antagonistic collective discourses of social classes" (1942). Accordingly, in Hamlet and King Lear, "the dramatic struggle between the major characters stages the ideological conflict between old, medieval ideals of kingship and the state and the modernizing tendencies of an emergent absolutist power that advances the interests of the bourgeoisie against the prerogatives of powerful feudal landlords" (1934). Similarly, Hamlet's "tendency toward obsessive individualistic reflection" (1934), under the influence of the new habits he acquired during his university education, conflicts with the feudal ideals embodied in his father and results in what seemed hesitation to kill his uncle. "The play stands, thematically and 
formally, on the cusp of a major historical transformation - the transition from feudalism to capitalism" (1934). Jameson sees that the play's ideological and formal contradictions are not resolved because it was too early to imagine the triumph of capitalism. At the same level, we cannot understand the conflict in Anton Chekhov's The Cherry Orchard, mainly between Ranyevskaia, the landlady, and Lopakhin, the businessman, except as the social and economic conflict between the declining Aristocrats and the rising bourgeoisie by the end of the $19^{\text {th }}$ century.

Terry Eagleton (1943-), the prominent English critic largely influenced by Louis Althusser's Marxist concepts in literary criticism, has also played a crucial role in developing the field of literary criticism, particularly the Marxist literary theory. Mulhern believes that Althusser's influence was so evident on Eagleton, who followed, though at a critical distance, with a "more comprehensive analysis centered on the notion of the literary as work in and on ideology." (13)

In his Marxism and literary Criticism (1976), Eagleton shows discontent with realist aesthetics and structuralism as a tool for literary criticism, shifting to the idea of literature as a social practice and to ways of determining the ideological conditions under which the literary work is produced. Asserting his belief that Marxist criticism has its significant role to play even in the transformation of human societies, he ironically claims that critics are not just analysts of texts, but they are also academics hired by the state to prepare students ideologically for their functions within capitalist society.

Similarly, in Criticism and Ideology (1976), Eagleton examines the relationship between literature and ideology, writing that the text may appear to be free in its use of ideology, or systems of representation, which shape the individual's picture of lived experience. In "Towards a Science of the Text" published in Criticism and Ideology, Eagleton contends that the "literary text is not the 'expression' of ideology, nor is ideology the 'expression' of social class. The text, rather, is a certain production of ideology" (qtd in Newton 171). He believes that a dramatic production does produce the text rather than 'express', 'reflect', or 'reproduce' it. This process, he reasons, transforms the text into "a unique and irreducible entity" (171), which, in turn, produces ideology. Similar to Althusser, he sees that Ideology "clearly signifies a 'false consciousness' which blocks true historical perception, a screen interposed between men and their history" (172). So, for Eagleton, history enters the text as ideology, which is destructured by the text to be reconstituted again as an artistic product. This complex relation means that a critic's task then is not to study the laws of ideological formations, but the laws of production of ideological discourses as literature. 
This is obviously based on the basic Marxist concept which analyzes literature according to modes of production dominant at a certain historical moment, governed by the prevailing ideology of the ruling class. To shed more light on this point, John Holcombe quotes Eagleton saying, "When Shakespear's texts cease to make us think, when we get nothing out of them, they will cease to have value. But why they 'make us think', why we 'get something out of them' (if only for the present) is a question which must be referred at once to the ideological matrix of our reading and the ideological matrix of their production." (8).

In "The Rise of English", published in Literary Theory: an Introduction (1983), Eagleton argues that literature concerns not simply beauty and spiritual elevation, but the social control of the middle and working classes, asserting that literature, like formal religion, is deeply involved in the reproduction of the dominant social order. Leitch sees that, "this survey of the discipline [English Literature] combines broad historical overview and ideological analysis" (2242). Going further than Jameson and Althusser, Eagleton believes that it is not necessary to speak of literature and ideology as two separate phenomena because "Literature, in the meaning of the word we have inherited, is an ideology" (2243). Exploring the role of religion in the Victorian age as an immensely powerful ideological form, and showing the trouble this ideology was facing in the Mid-Victorian period, especially under the effect of scientific discovery and social change, Eagleton believes that the philistine middle class, who were unable to bolster up their rising power with a powerful ideology, found the solution in English literature. So, what gives rise to English to become an academic subject was failure of religion to play its role, at least in its Victorian forms, as "a pacifying influence, fostering meekness, self-sacrifice and the contemplative inner life" (2244). To support his view, Eagleton quotes George Gordon, an early professor of English literature at Oxford, declaring that as the Churches have failed to offer remedies to England's social sickness, "English Literature has now a triple function: still, I suppose, to delight and instruct us, [...] and above all, to save our souls and heal the state" (2244). Considering Mathew Arnold as the key figure in using English literature for such a project, Eagleton harshly criticizes him for his relentless urge to "throw" the working-class children a few novels which "could provide a potent antidote to political bigotry and ideological extremism ... curb in them any disruptive tendency to collective political action...give them a pride in their national language and literature... so the pill of middle-class ideology was to be sweetened by the sugar of literature" (2245-2246).

However, in a revision of his previous views concerning the importance of theory, he says in a 1990 interview that this was a kind of fetishism of method, thinking then that he and other critics have to get a 
certain kind of systematic method to build on it. Yet, he came to know later that a "Marxist has to define certain urgent political goals and allow, as it were, those to determine questions of method rather than the other way around" ( 2241).

As a matter of fact, Eagleton's revision of his views was not limited to the literary theory, as he has also reconsidered his very concept of ideology and literature. In his The Ideology of the Aesthetic (1991), he emphasizes that with the emergence of the early bourgeoisie, aesthetic concepts began to play an unusual central part in the constitution of a dominant ideology. However, he makes it clear that he does not mean that "the eighteenth century bourgeoisie assembled around a table over their claret to dream up the concept of the aesthetic as a solution to their political dilemmas" (qtd in Regan 4). What he is trying to do in this book, as he assures, is to argue against "those critics for whom any linkage of aesthetics and political ideologies must appear scandalous or merely bemusing [and, strikingly enough,] those on the political left for whom the aesthetic is simply 'a bourgeois ideology', to be worsted and ousted by alternative forms of cultural politics" (8). He admits that certain works of art can be considered as a strong challenge to the controlling ideological forms. (3). It seems that in this same sense Eagleton reads D. H. Lawrence, seeing him "as unusual among twentieth-century writers in presenting both an intimate understanding of English society and a comprehensive radical criticism of its forms and directions” (4), where Sons and Lovers (1913) is his first major exploration of the problem of a man's relation to his own culture. The violence of Morel in Sons and Lovers, for example, might be seen just as brutal and degrading according to the bourgeois values, which Mrs. Morel, the "superior" daughter of an engineering foreman, embraces. However, Eagleton believes that Lawrence, unlike many middle-class observers, understands that "Morel's sullen obstinacy is more than animal stupidity: it is also the reflex habit of a long defensive tradition, developed by the English working class as a protection against patronage and manipulation from outside" (13). On this same basis, it seems, as James Smith writes in Terry Eagleton: A Critical Introduction (2008), that Eagleton studies the Brontes' works, uncovering political structures in different levels of the novels and using them to compare ideology in the sisters' works, thus "formulating a basis for a more objective aesthetic judgment concerning the superiority of Emily's Wuthering Heights over Charlotte's novels” (40). In this respect, Newton summarizes the shift in Eagleton's views, considering that his "more recent work has engaged with Althusserian Marxism and post structuralism without rejecting traditional Marxian concepts" (159). 
However, the inevitable question that rises here is: doesn't this apply too to Marxism itself? Weren't the Marxist ideologies in the former communist regimes in the Soviet Union and East European countries integrated in all aspects of life, including education and literature? This is not unlike what the ruling class did during McCarthyism in USA, interfering in every field of artistic production and leaving its impact not only on media but also on movies and literature. Unlike the American previous critical concept of comparative literature, for example, it has been proved later by many thinkers that studying literature and art is inextricably linked with the historical, social, and political moment of their production. Thus Edward Said wonders how colonial European countries can study and teach their history and, consequently, their artistic production of that period, separable from the history and culture of their ex-colonies. For him, both histories and literary, artistic, and philosophical production - of the colonizer and the colonized are inextricably linked and cannot be studied from a unilateral point of view. Thus it is undeniable that ideology does leave its fingerprints on literature and art as it does on all other aspects of life, despite the fact that there have always been novelists, poets, and playwrights who rebel against the discourse and hegemony of the mainstream and depict their own concepts of reality, which explains why many of them were persecuted in their own countries or become expatriates somewhere else.

\section{Conclusion}

To summarize, what one can conclude from the different views explored in this paper is that the Marxist literary theory has always been subject to considerable changes, yet with one constant invariable factor: the role of the ideology of the ruling class and the dominant system of values and beliefs is undeniable, thus ignoring this while analyzing and understanding literature, as well as other human artistic production, will be awkward, unrealistic and misleading.

To highlight the views discussed in this paper, it is suitable perhaps to quote Eagleton in Ideology: An Introduction. He writes:

For some thinkers, like late Karl Marx, ideology is less a matter of thought or discourse than of the very objective structure of class society itself. For others like Althusser, it is less consciousness than unconsciousness; for others again, ideology is less a 'tool' of a ruling power than an effect of a social and political situation as a whole , a complex field in which different groups and classes ceaselessly negotiate their relations rather than a wellbounded form of consciousness which can be neatly assigned to this group or the other...For the moment, 
however, we can stay with the conception of ideology as a set of discursive strategies for legitimating a dominant power, and enquire more precisely into what these strategies consist in (234).

In a word, despite all the diversity in how Marxist literary critics see the concept of ideology, still what they have in common is that "ideas are weapons in a field of struggle" (234). In short, it seems accurate to say with Walter Kendrick that literature "is an ideological term, all the more so because it pretends not to be. And professors of literature are ideologues, whether they call themselves deconstructionists or Arnoldians" (3).

\section{References:}

1. Althusser, Louis. (1971) Ideology and Ideology State Apparatuses. Trans. Ben Brewster. New York: Monthly Review Press.

2. --- Contradiction and Overdetermination. (1996). For Marx. Tras. Ben Brewster. New York: Verso.

3. Boehmer, Elleke. (1995). Colonial and Postcolonial Literature. USA: Oxford University Press.

4. Eagleton, Terry. (1976 a). Criticism and Ideology : A study in Marxist Literary Theory. New York and London: Verso.

5. --- (1976 b). Marxism and Literary Criticism. London: Verso.

6. --- (1983). Literary Theory: An introduction. University Minnesota Press.

7. --- (1991 a). Ideology: An Introduction. London: Verso.

8. --- (1991b). The ideology of the Aesthetic. Oxford: Blackwall.

9. Holcombe, John. (2005, July 17). Marxist Views: Overview. Retrieved from http://textetc.com.

10. Jameson, Fredric. (1971). Marxism and Form: twentieth-century Dialectical Theories of Literature. Princeton: Princeton University Press.

11. --- (1981). The Political Unconscious: Narrative as a Socially Symbolic Act. Ithaca, N.Y: Cornell University Press.

12. --- (1991). Postmodernism, or, The Cultural Logic of Late Capitalism. Durham, NC: Duke University Press.

13. Kellner, Douglas. (2009, January 20). Fredric Jameson. Retrieved from http://www.gseis.ucla.edu/faculty.

14. Kendrick, Walter. (1983, September 4). Criticism as Ideology. The New York Times. Retrieved from http://www. nytimes.com.

15. Leitch, Vincent B. (Ed.). (2001). The Norton Anthology of Theory and Criticism. New York and London: W. W. Norton and Company. 
16. Marks, Karl. (1846). A Critique of the German Ideology. Retrieved from

17. https://www.marxists.org.

18. --- (1859) A Contribution to the Critique of Political Economy. Retrieved from https://www.marxists.org.

19. --- (1863). Economic Manuscripts: Theories of Surplus Value, Ch IV. Retrieved from https://www.marxists.org. (pdf)

20. Mulhern,, Francis. (Ed.). (1992). Contemporary Marxist Literary Criticism. London and New York: Longman.

21. Newton, K.M. (Ed.). (1997). Twentieth-Century Literary Theory. New York: St.Martin's Press.

22. Regan, Stephen. (Ed.). (1998). The Eagleton Reader. WileyBlackwell.

23. Said, Edward. (1979). Orientalism. New York: Vintage Books.

24. Selden, Raman. (Ed.). (1988). The Theory of Criticism: From Plato to the Present. A Reader. London and New York: Longman.

25. Smith, James. (2008). Terry Eagleton: A Critical Introduction. Polity Press.

26. Sprawer, S.S. (1978). Karl Marx and World Literature. Oxford: Oxford University Press.

27. Tropical Experts from Interviews with Fredric Jameson. (2009, March 24). Stanford Presidential Lectures in the Humanities and Arts. Retrieved from http://prelectur.stanford.edu/lectures.

28. Williams, Jeffrey J. (1998). Theory and the Novel. Cambridge University Press, 1998. 